\title{
Sickle Cell to Erythrocyte Ratio Measurement
}

National Cancer Institute

\section{Source}

National Cancer Institute. Sickle Cell to Erythrocyte Ratio Measurement. NCI Thesaurus. Code C74656.

The determination of the ratio of sickle cells compared to all erythrocytes present in a sample. The measurement may be expressed as a ratio or percentage. 